\title{
イソオキサゾール類とエナミン類との反応による ピリジン類の生成
}

\author{
(1988 年 12 月 20 日受理)
}

太田和子*・岩岡純子・上條 裕子・岡田みどり・野村祐次郎

\begin{abstract}
イソオキサゾール類とエナミン類との反応により，ピリジン誘導体が生成することを見いだした。た と党ば、イソオキサゾールと 1-(1-シクロヘキセニル)ピロリシンを，THF またはジオキサン溶液中， 低原子価チタン塩（塩化チタン $(\mathbb{N})$ と亜鉛末から調製）の存在下還流して，1,2,3４-4ーテラヒドロキ， リンが得られた（収率 75\%)。同様の方法により，イソオキサゾール類と $\beta$ (または $\alpha$ )-置換エナミン から，種々の 3 (または 2)-位直換ピリジン類が得られた。しかし，5-メチルイソオキサゾール類との 反応では,ピリジン類の収率はきわめて低かった。
\end{abstract}

\section{1 腥 垔}

イソオキサゾール類 [1]は, 2,1-ベンゾイソオキサソール （アントラニル）と同様に 1 ーアザ-1, 3-ブタジェン構造を含み, [4+2] 付加環化の反応性 ${ }^{1} か ゙$ 注目されるが，現在までのところ， その反応例の報告はほとんどない。すなわち, Grandberg と Kost $^{2)}$ は，〔1]が一般のジェノフィルと Diels-Alder 反応を起 こさなかったことを報告している。イソオキサジールの化学につ いての Kochetkov と Sokolov の総説"), Wakefield と Wright の総説4), および Boger のアサジェンの Diels-Alder 反応につい ての総説"などにも，付加環化の反応例は見られない。大野と佐 々木は、へテロジェンの [4+2] 付加環化の総説(で, 〔1]は $\mathrm{Mo}(\mathrm{CO})_{B}$ の存在下, アセチレンジカルボン酸エステルと反応し, 低収率ながらピリシン誘尊体を与えたとの Kobayashi と Nitta の報告》を誉げているに過ぎない。

著者らは既報"に打いて, アントラニルとエナミン類との反応 により，[4+2] 付加璔化を経由してキノリン誘尊体が生成した ことを報告した。また, Komatsu らの 1-アザ-1, 3-ブタジェンと エナミン類との反纫による 3,5 -二㯰換ピリジン合成の報告8)があ 東京女子医科大学有機化学教室, 162 東京都新宿区河田 叮

1)太田和子, 消水弘子, 野村祐次郎, 日化, 1989, 846 .

2) I. I. Grandberg, A. N. Kost, Zh. Obshch. Khim., 29, 1099(1959).

3) N. K. Kochetkov, S. D. Sokolov, "Advances in Heterocyclic Chemistry," ed. A. R. Katritzky, Academic Press, New York, 2(1964) p. 365.

4) B. J. Wakefield, D. J. Wright, "Advances in Heterocyclic Chemistry," ed. A. R. Katritzky, A. J. Boulton, Academic Press, New York, 25(1979) p. 147.

5) D. L. Boger, Tetrahedron, 39, 2869(1983).

6) 大野正富, 佐↔木 正, 有合化, 42, 125(1984).

7) T. Kobayashi, M. Nitta, Chem. Lett., 1983, 1233.

8) M. Komatsu, S. Takamatsu, M. Uesaka, S. Yamamoto, Y. Ohshiro, T. Agawa, J, Org. Chem., 49, 2691(1984).
る。今回 [1]とエナミンとの反応を検討し、ピリシン誘導体を 得たので報告する。

\section{2 英験および結果}

\section{1 測定装}

${ }^{1} \mathrm{H}-\mathrm{NMR}$ の湘定には, 日立 R-24 B 型 $(60 \mathrm{MHz})$ を使用し,

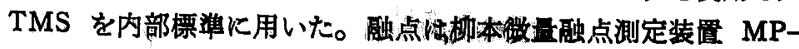
S 3 型で測定し未補正である。質量分析は東京薬科大学分析室 （日立二重収束型質量分析計 RMU-7 L 型使用）に，元素分析は 東京薬科大学分析室 (Perkin Elmer 240 B 型使用) または, 理研 分析センター（Perkin Elmer 240 型使用）飞依頖した。

\section{2 践}

イソオキサゾール類 [1]：イソオキサゾール[1-0], 5-メチル イソオキサゾール [1-8], 3,5-ジメチルイソオキサゾール[1-9] は, 市肘品を蒸留して使用した。

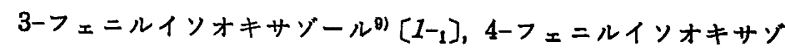

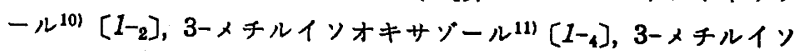
オキサゾール-4-カルボン酸エチル12)[1-6]，イソオキサゾール-3カルボン酸エチル13) [1-マ〕は，それぞれ文献に淮して合成した。

3,4-ジフェニルイソオキサゾール [1-8]; 3-メチルイソオキ廿 ゾールー4ーカルボン酸エチルを合成する文献12)の方法にしたがっ て、フェニルニトロメタン, イソシアン酸フェニルおよび 1-スチ リルピロリジンから 3,4-ジフェニル-5-ピロリジノ-2-イソオキ サゾリンを合成し，これをメタノールー塩酸と加熱䘞して合成し た。

9) R. Paul, S. Tchelitcheff, Bull. Soc. Chim. Fr. 1962, 2215.

10) H. Rupe, E. Knup, Helv. Chim. Acta, 10, 305(1927).

11) G. Soula, Ger. Offen, 1, 958, 252(Cl. CO 7 D) 27 May 1971, Appl. 20 Nov 1969.

12) G.Stork, J. E. McMurry, J. Am. Chem. Soc., 89, 5461(1967).

13) R. G. Micetich, Can. J. Chem., 48, 467(1970). 
Table 2 Yield $(\%)$ of pyridines [ 3 ] obtained by the reaction of isoxazoles [1-0 10] with enamines $[2 \mathrm{a} \sim \mathrm{g}]$

\begin{tabular}{|c|c|c|c|c|c|c|c|c|c|c|c|c|c|c|}
\hline \multirow[b]{2}{*}{$\begin{array}{l}\text { Iso- } \\
\text { xazoles }\end{array}$} & \multicolumn{2}{|c|}{ a } & \multicolumn{2}{|c|}{ b } & \multicolumn{2}{|c|}{ c } & \multicolumn{2}{|c|}{ d } & \multicolumn{2}{|c|}{ e } & \multicolumn{2}{|c|}{$f$} & \multicolumn{2}{|c|}{$\mathbf{g}$} \\
\hline & [3] & $\begin{array}{l}\text { Yield } \\
(\%)\end{array}$ & [3] & $\begin{array}{l}\text { Yield } \\
(\%)\end{array}$ & {$[3]$} & $\begin{array}{c}\text { Yield } \\
(\%)\end{array}$ & [3] & $\begin{array}{c}\text { Yield } \\
(\%)\end{array}$ & [3] & $\begin{array}{l}\text { Yield } \\
(\%)\end{array}$ & [3] & $\begin{array}{c}\text { Yield } \\
(\%)\end{array}$ & [3] & $\begin{array}{l}\text { Yield } \\
(\%)\end{array}$ \\
\hline$[1-0]$ & $a-0$ & - & $b-0$ & 75 & $c-0$ & - & $d-0$ & 20 & $e-0$ & 65 & $f-0$ & 39 & & \\
\hline$[1-1]$ & $a-1$ & 32 & $b-1$ & 65 & $c-1$ & 48 & $\mathrm{~d}-{ }_{1}$ & 37 & $e-1$ & 27 & $f-1$ & 58 & $g-1$ & - \\
\hline$[1-2]$ & $a-2$ & 54 & $b-2$ & 64 & $\mathrm{C}-2_{2}$ & 25 & $d-2$ & 36 & $e-2$ & 55 & $f-2$ & 42 & $g-2$ & 54. \\
\hline$[1-8]$ & $a-3$ & 70 & $\mathrm{~b}-{ }_{3}$ & 37 & $c-8$ & 21 & $d-8$ & 31 & $e-8$ & 26 & $f-8$ & 44 & $g-8$ & 27 \\
\hline$[1-4]$ & $a-4$ & 13 & $\mathrm{~b}-4$ & 13 & $c-4$ & 24 & $d-4$ & 15 & e-4 & 25 & $f-4$ & 27 & & \\
\hline$[1-5]$ & $a-s$ & 25 & $b-5$ & 31 & $c-s$ & 18 & $d-\xi$ & 27 & $e-5$ & 25 & $f-3$ & 31 & $\mathrm{~g}-\mathrm{s}$ & 8 \\
\hline$[1-6]$ & $a-6$ & 15 & $b-6$ & 11 & $c_{-6}$ & 4 & $d-\theta$ & 16 & $e-6$ & 9 & $f-8$ & 16 & g-6 & - \\
\hline$[1-\eta]$ & $a-7$ & 11 & $b-7$ & $*$ & $c-7$ & $*$ & $d-7$ & $*$ & $e-7$ & $*$ & $f-7$ & $*$ & $g-7$ & - \\
\hline$[1-8]$ & & & $b-8$ & $*$ & $c-8$ & - & & & & & & & $g-8$ & - \\
\hline$[1-0]$ & & & $b-0$ & - & $c-\vartheta$ & - & & & & & & & $g-0$ & 9 \\
\hline$\left[1-{ }_{10}\right]$ & & & $b-10$ & - & $C-{ }_{10}$ & - & & & & & & & $g-10$ & 9 \\
\hline
\end{tabular}

$\left.\mathrm{C}_{6} \mathrm{H}_{5}\right), 9.00(1 \mathrm{H}, \mathrm{s}, 5-\mathrm{CH})$

5-メチル-3-フェニルイソオキサゾール-4-カルボン酸エチル [1-10]; 市販の 5-メチル-3-フェニルイソオキ+ゾール-4-カルボ ン酸をエステル化して使用した。 $\mathrm{mp} 49 \sim 50^{\circ} \mathrm{C}$ (文献值 ${ }^{16)} 49 \sim 50^{\circ} \mathrm{C}$ )

エナミン〔2]：1-(シクロペンテニル)ピロリジン[2a], 1(1-シクロヘキセニル)ピロリジン [2b], 1-(1-ブテニル)ピロリ ジン [2 c ], 1-(3-メチル-1-ブテニル)ピロリジン [2d], 1-(3-フ エニル-1-プロペニル)ピロリジン [2e]，1-スチリルピロリジン 〔2f〕は，既報に報告した方法昼で合成した。

1-イソプロペニルピロリジン [2g]は，文献17)にしたがって合 成した。

\section{3 ピリジン類 [3]の合成}

アルゴン缱換した $200 \mathrm{ml}$ の三つロフラスコにジオキサン 20 $\mathrm{m} l$ と亜鉛末 $0.4 \mathrm{~g}(6 \mathrm{mmol})$ を入れ, 氷冷しかきまぜながら塩化 チタン $(\mathrm{N}) 1.9 \mathrm{~g}(10 \mathrm{mmol})$ を滴下後, 室温で 1.5 時間反応さ せたこ。の低原子価チタン塩を含む孯濁夜を加熱・還流しなが ら，ジオキサン $8 \mathrm{ml}$ Kイソオキサゾール類 [1-0 10 $5 \mathrm{mmol}$ と エナミン $[2 \mathrm{a} \sim \mathrm{g}] 20 \mathrm{mmol}$ を溶かした溶液を滴下し，TLC で 反応の進行を調べながら 1〜3 時間還流した。[1-0] と [2 b]， [2d]拉よび [1-8] と[2 c ] との反応では, ジオキサンの代わり にTHF を溶媒とし 1 時間遇流した。反応後 $\mathrm{K}_{2} \mathrm{CO}_{3} 20 \%$ 水溶液 $8 \mathrm{~m} l$ を加えてかきまぜ, 上澄み液をデカンテーションにより别 ち， $\mathrm{CH}_{2} \mathrm{Cl}_{2}$ で沈股物を洗い，合わせた有機靖を $\mathrm{Na}_{2} \mathrm{SO}_{4}$ で乾燥 後，溶媒を減圧留去した。残留分はカラムクロマトグラフィー （シリカゲル $50 \mathrm{~g}$ ）に付 し， $\mathrm{CH}_{2} \mathrm{Cl}_{2}$ またはへキサン+ $\mathrm{Et}_{2} \mathrm{O}$ で溶 出し，ピリシン部分を集め、これをさらに分取 TLC, bulb to bulb 蒸留, 再結晶などで精製し，ピリジン類〔3〕を得た。収率 は表 2 に示す。

合成されたピリジン類のうち既知化合物は，遊離塩毞またはピ クラートの融点と文嗝の融点を記城した。文献値と䱊なる化合物 执よび文献にない化合物については，元絜分析または High MS

16) E. Benary, Ber., 42, 3924(1909).

17) H. Ahlbrecht, W. Raab, Synthesis, 1980, 320.
の結果を示した。これらの化合物は ${ }^{1} \mathrm{H}-\mathrm{NMR}$ スペクトルにより 目的のピリジンであることを確かめた。

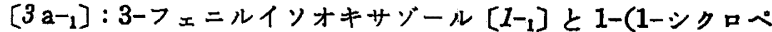
ンテニル)ビロリジン [2a] を用いて，2-フェニル-6,7-ジヒド ロ-5H-シクロペンタ $[b]$ ビリシン [3a-1]を得た。 $\mathrm{mp} 83 \sim 84^{\circ} \mathrm{C}$ (文嗝値 ${ }^{18)} 80^{\circ} \mathrm{C}$ )

ピクラート : $\mathrm{mp} 200^{\circ} \mathrm{C}$ (文献值 ${ }^{18)} 198^{\circ} \mathrm{C}$ )。

[3a-2] : 4-フェニルイソオキサゾール [1-2] と [2a]を用い て, 3-フェニル-6, 7-ジヒドロ -5 H-シクロペンタ[b]ピリジン [3 $\mathrm{a}-2]$ を得た。

リグロインから再結晶，無色針状晶， mp $95^{\circ} \mathrm{C}$

${ }^{1} \mathrm{H}-\mathrm{NMR}\left(\mathrm{CDCl}_{8}\right) \delta: 1.95 \sim 2.45\left(2 \mathrm{H}, \mathrm{m}, 6-\mathrm{CH}_{2}\right), 2.80 \sim$ 3. $23\left(4 \mathrm{H}, \mathrm{m}, 5,7-\mathrm{CH}_{2}\right), 7.28 \sim 7.75(6 \mathrm{H}, \mathrm{m}, 4-\mathrm{CH}$,

$\left.\mathrm{C}_{6} \mathrm{H}_{5}\right), 8.58(1 \mathrm{H}, \mathrm{d}, 2-\mathrm{CH})$

分析値 C $86.10 \%, \mathrm{H} 6.75 \%, \mathrm{~N} 7.06 \%$ $\mathrm{C}_{14} \mathrm{H}_{18} \mathrm{~N}$ としての

計算値 C $86.12 \%, \mathrm{H} 6.71 \%, \mathrm{~N} 7.17 \%$

[3a-8] : 3,4-ジフェニルイソオキサゾール[1-g]と[2a]を用 いて, 2,3-ジフェニル-6,7-ジヒドロ $-5 H$-シクロペンタ[b]ピリ ジンを得た。

ヘキサンから再結晶, 微黄色針状晶, $\mathrm{mp} 161.5 \sim 162^{\circ} \mathrm{C}$

${ }^{1} \mathrm{H}-\mathrm{NMR}\left(\mathrm{CDCl}_{3}\right) \delta: 2.0 \sim 2.45\left(2 \mathrm{H}, \mathrm{m}, 6-\mathrm{CH}_{2}\right), \quad 2.85 \sim$ 3. $30\left(4 \mathrm{H}, \mathrm{m}, 5,7-\mathrm{CH}_{2}\right), 7.00 \sim 7.45\left(10 \mathrm{H}, \mathrm{m}, 2,3-\mathrm{C}_{6} \mathrm{H}_{3}\right)$, $7.52(1 \mathrm{H}, \mathrm{s}, 4-\mathrm{CH})$

分析値 C $88.41 \%, \mathrm{H} 6.37 \%, \mathrm{~N} 5.15 \%$

$\mathrm{C}_{20} \mathrm{H}_{17} \mathrm{~N}$ としての

計算值 C $88.52 \% ， \mathrm{H} 6.31 \% ， \mathrm{~N} 5.16 \%$

[3a-4]:3-メチルイソオキサゾール[1-4] と [2a]を用いて, 2-メチル-6, 7-ジヒドロ-5 H-シクロペンタ [b].ピリジン [3a-4] を得た。

白色針状晶, $\mathrm{mp} 30^{\circ} \mathrm{C}$

ピクラート: $\mathrm{mp} 148 \sim 150^{\circ} \mathrm{C}$ (文献值 ${ }^{19)} 149 \sim 150^{\circ} \mathrm{C}$ )

18) N. S. Gill, K. B. James, F. Lion, K. T. Potts, J. Am. Chem. Soc., 74, 4923(1952). 
[3a-5] : 3-フェニルイソオキサゾール-4-カルボン酸エチル [1-s] と[2a]を用いて, 2-フェニル-6,7-ジヒドロ -5 H-シクロ ペンタ $[b]$ ピリシンー3-カルボン酸エチル [3a-5]を得た。

無色油状

${ }^{1} \mathrm{H}-\mathrm{NMR}\left(\mathrm{CDCl}_{3}\right) \delta: 0.99\left(3 \mathrm{H}, \mathrm{t}, J=7.2 \mathrm{~Hz},-\mathrm{CH}_{2}-\mathrm{CH}_{3}\right)$, $2.0 \sim 2.50\left(2 \mathrm{H}, 6-\mathrm{CH}_{2}\right), 2.80 \sim 3.30\left(4 \mathrm{H}, \mathrm{m}, 5,7-\mathrm{CH}_{2}\right)$, $4.10\left(2 \mathrm{H}, \mathrm{q}, J=7.2 \mathrm{~Hz}, \mathrm{CH}_{2}-\mathrm{CH}_{3}\right), 7.22 \sim 7.62(5 \mathrm{H}, \mathrm{m}$, $\left.\mathrm{C}_{6} \mathrm{H}_{5}\right), 7.90(1 \mathrm{H}, \mathrm{s}, 4-\mathrm{CH})$

分析值 C $76.11 \%, \mathrm{H} 6.42 \%, \mathrm{~N} 5.40 \%$

$\mathrm{C}_{17} \mathrm{H}_{17} \mathrm{NO}_{2}$ としての

計算值 C $76.38 \% ， \mathrm{H} 6.41 \% ， \mathrm{~N} 5.24 \%$

ピクラート：EtOH から再結晶, 黄色りん片状晶, $\mathrm{mp} 126^{\circ} \mathrm{C}$

分析値 C $55.56 \%, \mathrm{H} 4.04 \%, \mathrm{~N} 11.28 \%$

$\mathrm{C}_{28} \mathrm{H}_{20} \mathrm{~N}_{4} \mathrm{O}_{9}$ としての

計算值 C $55.65 \%, \mathrm{H} 4.06 \%, \mathrm{~N} 11.29 \%$

[3a-8]:3-メチルイソオキサゾール-4-カルボン酸エチル[1-6]

と [2a]を用いて，2-メチル-6,7-ジヒドロ-5 H-シクロペンタ $[b]$ ピリジン-3-カルボン酸エチル [3 $\left.\mathrm{a}-_{6}\right]$ を得た。

無色油状, ${ }^{1} \mathrm{H}-\mathrm{NMR}$ は文献 ${ }^{201}$ と一致した。

ピクラート： $\mathrm{EtOH}$ から再結晶，黄色りん片状晶, $\mathrm{mp} \mathrm{136〜}$ $138^{\circ} \mathrm{C}$ (文献值 ${ }^{20}{ }^{\circ} 123 \sim 124^{\circ} \mathrm{C}$ )

分析値 $\mathrm{C} 49.49 \%, \mathrm{H} 4.13 \%, \mathrm{~N} 12.83 \%$

$\mathrm{C}_{18} \mathrm{H}_{18} \mathrm{~N}_{4} \mathrm{O}_{9}$ としての

計算值 C $49.77 \% ， \mathrm{H} 4.18 \% ， \mathrm{~N} 12.90 \%$

[3a-7]:イソオキサゾール-3-カルボン酸エチル[1-7] [2a]を用いて，2-(1-ピロリジニルカルボニル)-6,7-ジヒドロー $5 H$-シクロペンタ $[b]$ ピリジン [3a-7]を得た。

ヘキサンから再結晶, 無色針状晶, $\mathrm{mp} 68 \sim 69^{\circ} \mathrm{C}$

${ }^{1} \mathrm{H}-\mathrm{NMR}\left(\mathrm{CDCl}_{3}\right) \delta: 1.70 \sim 2.44\left(6 \mathrm{H}, \mathrm{m}, 6-\mathrm{CH}_{2}\right.$, ピロリジ 環 $\left.\stackrel{(8)}{\mathrm{C}}_{2}-\stackrel{(4)}{\mathrm{CH}}_{2}\right), 2.80 \sim 3.20\left(4 \mathrm{H}, \mathrm{m}, 5,7-\mathrm{CH}_{2}\right), \quad 3.50 \sim 3.86$ $\left(4 \mathrm{H}, \mathrm{m}\right.$, ピロリジン環 $\left.\stackrel{(2)}{\mathrm{C}}_{2}-\mathrm{CH}_{2} \mathrm{CH}_{2}\right) ; 7.40(2 \mathrm{H}, \mathrm{s}, 3,4-\mathrm{CH})$

分析值 C $72.21 \%, \mathrm{H} 7.40 \%, \mathrm{~N} 12.88 \%$

$\mathrm{C}_{13} \mathrm{H}_{18} \mathrm{~N}_{2} \mathrm{O}$ としての

計算値 C $72.19 \%, \mathrm{H} 7.46 \%, \mathrm{~N} 12.95 \%$

[3 b-0 $]$ : イソオキサヅール [1-0 $]$ と 1-(1-シクロへキセニル) ピロリシンン [2b]を用いて, $5,6,7,8$-テトラヒドロキノリン [3 b-0 $]$ を得た。

無色油状, ピクラート：mp 160 161. $5^{\circ} \mathrm{C}$ (文献值 ${ }^{21)} 159 \sim$ $160^{\circ} \mathrm{C}$ )

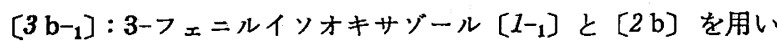
て, 2-フェニル-5,6,7,8-テトラヒドロキノリン [3 b-1]を得た。

無色油状 bp $160 \sim 170^{\circ} \mathrm{C} / 3 \mathrm{mmHg}$ (bulb to bulb 蒸留), (ピ クラート文献値 ${ }^{22)} \mathrm{mp} 165^{\circ} \mathrm{C}$ )

分析值 C $85.93 \%, \mathrm{H} 7.27 \%, \mathrm{~N} 6.57 \%$

$\mathrm{C}_{15} \mathrm{H}_{15} \mathrm{~N}$ としての

19) J.Epsztajn, W.E.Hahn, B. K. Tosik, Rocz. Chem., 44, 431(1970).

20) G. Bouchon, K. -H. Spohn, E. Breitmaier, Chem. Ber., 106, 1736(1973).

21) F. W. Vierhapper, E. L. Eliel, J. Am. Chem. Soc., 96, 2256(1974).

22) G. N. Dorofeenko, G. I. Zhungietu, Zh. Obshch. Khim., 35, 589(1965).
計算値 C $86.08 \% ， \mathrm{H} 7.22 \% ， \mathrm{~N} 6.69 \%$

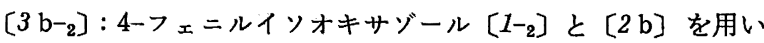
て, 3-フェニル-5, 6,7,8-テトラヒドロキノリン [3 b-2 $]$ を得た。 無色油状 (塩酸塩 文献 ${ }^{23)} \mathrm{mp} 235^{\circ} \mathrm{C}$ )

ピクラート：EtOH から再結晶, 黄色りん片状晶, mp 192 $194^{\circ} \mathrm{C}$

分析値 C $57.60 \%, \mathrm{H} 4.10 \%, \mathrm{~N} 12.74 \%$

$\mathrm{C}_{12} \mathrm{H}_{18} \mathrm{~N}_{4} \mathrm{O}_{7}$ としての

計算値 C $57.53 \% ， \mathrm{H} 4.14 \% ， \mathrm{~N} 12.78 \%$

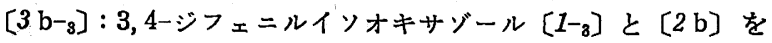
用いて，2,3-ジフェニル-5, 6, 7, 8-テトラヒドロキノリン $[3 \mathrm{~b}-8]$ を得た。

$\mathrm{mp}: 124.5 \sim 125^{\circ} \mathrm{C}$ (文献値 ${ }^{24)} 123^{\circ} \mathrm{C}$ )

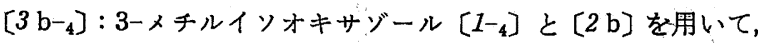
2 -メチル $-5,6,7,8$-テトラヒドロキノリン [3 b- $\left.{ }_{4}\right]$ を得た。

無色油状, ピクラート：mp 158 159. $5^{\circ} \mathrm{C}$ (文献值 ${ }^{21)} 158 \sim$ $\left.159^{\circ} \mathrm{C}\right)$

[3 b-5] : 3-フェニルイソオキサゾール-4-カルボン酸ェチル [1-5] と[2b] から，2-フェニル-5, 6,7,8-テトラヒドロキノリ ンー3ーカルボン酸エチル [3 b-5]を得た。

無色油状

${ }^{1} \mathrm{H}-\mathrm{NMR}\left(\mathrm{CDCl}_{3}\right) \delta ; 0.97\left(3 \mathrm{H}, \mathrm{t}, J=7.2 \mathrm{~Hz}, \mathrm{CH}_{2} \mathrm{CH}_{3}\right)$, $1.65 \sim 2.15\left(4 \mathrm{H}, \mathrm{m}, 6,7-\mathrm{CH}_{2}\right), 2.60 \sim 3.15(4 \mathrm{H}, \mathrm{m}, 5,8-$ $\left.\mathrm{CH}_{2}\right), 4.06\left(2 \mathrm{H}, \mathrm{q}, \mathrm{J}=7.2 \mathrm{~Hz}, \mathrm{CH}_{2} \mathrm{CH}_{3}\right), 7.25 \sim 7.60(5 \mathrm{H}$, $\left.\mathrm{m}, \mathrm{C}_{6} \mathbf{H}_{5}\right), 7.79(1 \mathrm{H}, \mathrm{s}, 4-\mathrm{CH})$

分析值 C $76.80 \%, \mathrm{H} 6.80 \%, \mathrm{~N} 4.95 \%$

$\mathrm{C}_{13} \mathrm{H}_{19} \mathrm{NO}_{2}$ としての

計算值 C $76.84 \%, \mathrm{H} 6.81 \%, \mathrm{~N} 4.98 \%$

ピクラート: EtOH から再結晶, 黄色りん片状晶, $\mathrm{mp} \mathrm{151.5〜}$ $152^{\circ} \mathrm{C}$

分析值 C $56.32 \%, \mathrm{H} 4.31 \%, \mathrm{~N} 10.89 \%$

$\mathrm{C}_{24} \mathrm{H}_{22} \mathrm{O}_{9} \mathrm{~N}_{4}$ としての

計算值 C $56.47 \%, \mathrm{H} 4.34 \%, \mathrm{~N} 10.98 \%$

[3 b-8] : 3-メチルイソオキサゾール-4-カルボン酸エチル $[1-8]$ と [2 b]を用いて, 2-メチル-5, 6, 7, 8-テトラヒドロキノリン-3カルボン酸エチル [3 b-B]を得た。

無色油状, ピクラート：EtOH から再結晶, 黄色針状晶, mp $149 \sim 150^{\circ} \mathrm{C}$ (文献値 ${ }^{20)} 144 \sim 145^{\circ} \mathrm{C}$ )

分析值 C $50.91 \%, \mathrm{H} 4.45 \%, \mathrm{~N} 12.56 \%$

$\mathrm{C}_{19} \mathrm{H}_{20} \mathrm{~N}_{4} \mathrm{O}_{7}$ としての

計算值 C $50.90 \%, \mathrm{H} 4.50 \%, \mathrm{~N} 12.50 \%$

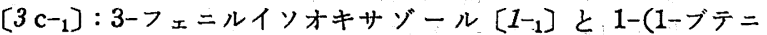
ル）ピロリジン [2c]を用いて, 5-エチル-2-フェニルピリジン [3 c-1]を得た。

へキサンから再結晶, 無色針状晶, mp 58.5 59 ${ }^{\circ} \mathrm{C}$ (文献 ${ }^{25)}$ K は黄色固体，融点の記載なし）

23) J.v. Braun, A. Petzold, J. Seeman, Ber., 55 B, 3779 (1922).

24) D. J. Brien, A. Naiman, K. P. C. Vollhardt, J. Chem. Soc., Chem. Commun., 1982, 133.

25) R. F. Francis, C. D. Crews, B. S. Scott, J. Org. Chem., 43, 3227(1978). 
分析値 C $85.12 \%, \mathrm{H} 7.01 \%, \mathrm{~N} 7.60 \%$

$\mathrm{C}_{13} \mathrm{H}_{13} \mathrm{~N}$ としての

計算値 C $85.21 \%, \mathrm{H} 7.15 \%, \mathrm{~N} 7.65 \%$

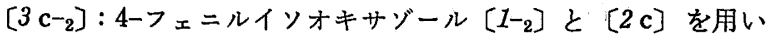
て，3-ェチル-5-フェニルピリシン [3 c-i $]$ を得た。

無色油状, ピクラート：mp 157 $158^{\circ} \mathrm{C}$ (文献値 ${ }^{8)} 158 \sim 159^{\circ} \mathrm{C}$ )。 $\left[3 \mathrm{c}-{ }_{3}\right]: 3,4-シ ゙ フ ェ ニ ル イ ソ オ キ サ ソ ゙ ー ル\left[1-r_{3}\right]$ と [2 c $]$ を用 いて，5-エチル-2,3-ジフェニルピリジン [3 c-3]を得た。

無色針状晶, $\mathrm{mp} 72 \sim 73^{\circ} \mathrm{C}$

${ }^{1} \mathrm{H}-\mathrm{NMR}\left(\mathrm{CDCl}_{3}\right) \delta: 1.31\left(3 \mathrm{H}, \mathrm{t}, \quad J=7.2 \mathrm{~Hz}, \mathrm{CH}_{2} \mathrm{CH}_{3}\right)$, $2.73\left(2 \mathrm{H}, \mathrm{q}, J=7.2 \mathrm{~Hz}, \mathrm{CH}_{2} \mathrm{CH}_{8}\right), 7.05 \sim 7.43(10 \mathrm{H}, \mathrm{m}$, $\left.2,3-\mathrm{C}_{6} \mathrm{H}_{5}\right), 7.51(1 \mathrm{H}, \mathrm{d}, J=2.0 \mathrm{~Hz}, 4-\mathrm{CH}), 8.53(1 \mathrm{H}, \mathrm{d}$, $J=2.0 \mathrm{~Hz}, 6-\mathrm{CH}$ )

分析値 C $88.24 \%, \mathrm{H} 6.60 \%, \mathrm{~N} 5.48 \%$

$\mathrm{C}_{19} \mathrm{H}_{17} \mathrm{~N}$ としての

計算值 C $87.99 \%, \mathrm{H} 6.61 \%, \mathrm{~N} 5.40 \%$

[3 c-4]:3-メチルイソオキサゾール [1-4] と[2c]を用いて, 5-エチル-2-メチルピリジン [3 c-4] を得た。

無色油状, ピクラート：mp 165 $166^{\circ} \mathrm{C}$ (文献値 ${ }^{26)} 166 \sim 168^{\circ} \mathrm{C}$ )

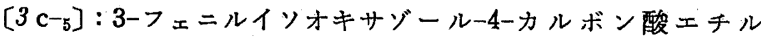
[1-5]と〔2c]を用いて, 5-エチル-2-フェニルピリジン-3-カル ボン酸エチル [3 c-5]を得た。

無色油状, bp $150^{\circ} \mathrm{C} / 4 \mathrm{mmHg}$ (bulb to bulb 蒸留)

${ }^{1} \mathrm{H}-\mathrm{NMR}\left(\mathrm{CDCl}_{3}\right) \delta: 1.01\left(3 \mathrm{H}, \mathrm{t}, J=7.2 \mathrm{~Hz}, \mathrm{COOCH}_{2}\right.$. $\left.\mathrm{CH}_{3}\right), 1.29\left(3 \mathrm{H}, \mathrm{t}, J=7.2 \mathrm{~Hz}, \mathrm{CH}_{2} \mathrm{CH}_{3}\right) ; 2.72(2 \mathrm{H}, \mathrm{q}$, $\left.J=7.2 \mathrm{~Hz}, \mathrm{CH}_{2} \mathrm{CH}_{8}\right), 4.10\left(2 \mathrm{H}, \mathrm{q}, J=7.2 \mathrm{~Hz}, \operatorname{COOCH}_{2}\right.$. $\left.\mathrm{CH}_{8}\right), 7.20 \sim 7.60\left(5 \mathrm{H}, \mathrm{m}, \mathrm{C}_{8} \mathrm{H}_{5}\right), 7.86(1 \mathrm{H}, \mathrm{d}, J=2.2$ $\mathrm{Hz}, 4-\mathrm{CH}), 8.55(1 \mathrm{H}, \mathrm{d}, J=2.2 \mathrm{~Hz}, 6-\mathrm{CH})$

分析值 C $75.06 \%, \mathrm{H} 6.66 \%$ ， N $5.43 \%$

$\mathrm{C}_{18} \mathrm{H}_{17} \mathrm{NO}_{2}$ としての

計算値 C $75.27 \% ， \mathrm{H} 6.71 \% ， \mathrm{~N} 5.49 \%$

[3c-6] : 3-メチルイソオキサゾール-4-カルボン酸エチル[1-6] と〔2 c]を用いて，5-ェチル-2-メチルピリジン-3-カルポン酸エ チル [3 c-6]を得た。

無色油状

${ }^{1} \mathrm{H}-\mathrm{NMR}\left(\mathrm{CDCl}_{3}\right) \delta: 1.26\left(3 \mathrm{H}, \mathrm{t}, J=7.2 \mathrm{~Hz}, \mathrm{CH}_{2} \mathrm{CH}_{3}\right)$, $1.40\left(3 \mathrm{H}, \mathrm{t}, J=7.2 \mathrm{~Hz}, \mathrm{COOCH}_{2} \mathrm{CH}_{3}\right), 2.66(2 \mathrm{H}, \mathrm{q}, J=$ $\left.7.2 \mathrm{~Hz}, \mathrm{CH}_{2} \mathrm{CH}_{3}\right), 2.77$ ( $\left.3 \mathrm{H}, \mathrm{s}, 2-\mathrm{CH}_{3}\right), 4.36(2 \mathrm{H}, \mathrm{q}, J=$ $\left.7.2 \mathrm{~Hz}, \operatorname{COOCH}_{2} \mathrm{CH}_{8}\right), 7.97(1 \mathrm{H}, \mathrm{d}, J=2.0 \mathrm{~Hz}, 4-\mathrm{CH})$, $8.42(1 \mathrm{H}, \mathrm{d}, J=2.0 \mathrm{~Hz}, 6-\mathrm{CH})$

ピクラート： $\mathrm{EtOH}$ から再結晶, 黄色針状晶, $\mathrm{mp} 104^{\circ} \mathrm{C}$ (文献 值 ${ }^{27)} 112 \sim 113.5^{\circ} \mathrm{C}$ )

分析値 C $48.39 \%, \mathrm{H} 4.24 \%, \mathrm{~N} 13.24 \%$

$\mathrm{C}_{17} \mathrm{H}_{18} \mathrm{~N}_{4} \mathrm{O}_{9}$ としての

計算值 C $48.35 \%, \mathrm{H} 4.30 \%, \mathrm{~N} 13.27 \%$

$\left[3 \mathrm{~d}--_{0}\right]:$ イソオキサゾール [1-0 $]$ と 1-(3-メチル-1-ブテ= ル)ピロリジン $[2 \mathrm{~d}]$ を用いて，3-イソプロピルピリジン $[3 \mathrm{~d}-0]$ を得た。

無色油状, ピクラート：mp 137 $138^{\circ} \mathrm{C}$ (文献值 ${ }^{28)} 138^{\circ} \mathrm{C}$ )

26) C. P. Farley, E. L. Eliel, J. Am. Chem. Soc., 78, 3477 (1956).

27) H. D. Eilhauer, I. Kämpfer, Z. Chem., 9, 188(1969).
$[3 \mathrm{~d}-1]: 3-フ ェ$ ニルイソオキサゾール[1-1 $]$ と [2d]を用い て，5-イソプロピル-2-フェニルピリジン [3d-1] を得た。 $\mathrm{mp} 53^{\circ} \mathrm{C}$ (文献値 ${ }^{29)} 53 \sim 53.5^{\circ} \mathrm{C}$ )

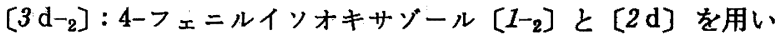
て, 5-イソプロピル-3-フェニルピリシン [3 d-2 $]$ を得た。

無色油状, bp $100^{\circ} \mathrm{C} / 3 \mathrm{mmHg}$ (bulb to bulb 蒸留)

${ }^{1} \mathrm{H}-\mathrm{NMR}\left(\mathrm{CDCl}_{3}\right) \delta: 1.30(6 \mathrm{H}, \mathrm{d}, J=7.0 \mathrm{~Hz}$, イソブロピル $\left.\mathrm{CH}_{3}\right), 3.0(1 \mathrm{H}$, sept, $J=7.0 \mathrm{~Hz}$, イソブロピル $\mathrm{CH}), 7.25$ $\sim 7.75\left(6 \mathrm{H}, \mathrm{m}, 4-\mathrm{CH}, \mathrm{C}_{6} \mathrm{H}_{5}\right), 8.48(1 \mathrm{H}, \mathrm{d}, J=2.0 \mathrm{~Hz})$, $8.67(1 \mathrm{H}, \mathrm{d}, J=2.0 \mathrm{~Hz})$

High MS m/e 197.1195

$\mathrm{C}_{14} \mathrm{H}_{15} \mathrm{~N}_{1}$ としての計算値 197.1203

ピクラート： EtOH から再結晶, 黄色針状晶, mp 156 157 ${ }^{\circ} \mathrm{C}$ 分析値：C $56.34 \%, \mathrm{H} 4.24 \%, \mathrm{~N} 13.11 \%$

$\mathrm{C}_{20} \mathrm{H}_{18} \mathrm{~N}_{4} \mathrm{O}_{7}$ としての 計算値 C $56.34 \%, \mathrm{H} 4.25 \%, \mathrm{~N} 13.14 \%$

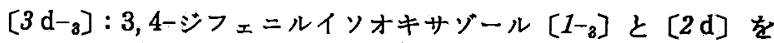
用いて, 5-イソプロピル-2,3-ジフェニルピリシン [3d-8] を得 た。

リグロインから再結晶, '無色りん片状晶, mp 114 114. $5^{\circ} \mathrm{C}$

${ }^{1} \mathrm{H}-\mathrm{NMR}\left(\mathrm{CDCl}_{3}\right) \delta: 1.40(6 \mathrm{H}, \mathrm{d}, J=7.0 \mathrm{~Hz}$, イソブロピル $\left.\mathrm{CH}_{3}\right), 3.05(1 \mathrm{H}$, sept, $J=7.0 \mathrm{~Hz}$, イソプロピル CH), 7.12 $\sim 7.50\left(10 \mathrm{H}, \mathrm{m}, 2,3-\mathrm{C}_{6} \mathrm{H}_{5}\right), 7.63(1 \mathrm{H}, \mathrm{d}, J=2.0 \mathrm{~Hz}, 4-$ $\mathrm{CH}), 8.64(1 \mathrm{H}, \mathrm{d}, J=2.0 \mathrm{~Hz}, 6-\mathrm{CH})$

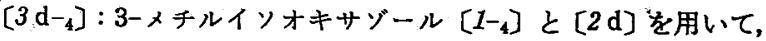
5-イソプロピル-2-メチルピリジン $[3 \mathrm{~d}-1]$ を得た。

無色油状, ピクラート : $\mathrm{mp} 167^{\circ} \mathrm{C}$ (文献值 ${ }^{30)} \mathrm{mp} 167 \sim 168^{\circ} \mathrm{C}$ ) [3d-5]:3-フェニルイソオキサゾール-4-カルポン酸エチル [1-5]と[2d]を用いて, 5-イソプロピル-2-フェニルピリシシンー 3ーカルボン酸エチル [3d-5] を得た。

無色油状, bp $140^{\circ} \mathrm{C} / 4 \mathrm{mmHg}$ (bulb to bulb 蒸留)

${ }^{1} \mathrm{H}-\mathrm{NMR}\left(\mathrm{CDCl}_{3}\right) \delta: 1.01\left(3 \mathrm{H}, \mathrm{t}, J=7.0 \mathrm{~Hz}, \mathrm{COOCH}_{2}\right.$. $\left.\mathrm{CH}_{3}\right), 1.32\left(6 \mathrm{H}, \mathrm{d}, J=7.0 \mathrm{~Hz}\right.$, イソプロピル $\left.\mathrm{CH}_{8}\right), \quad 3.03$ $(1 \mathrm{H}$, sept, イソプロピル CH), $4.11(2 \mathrm{H}, \mathrm{q}, J=7.0 \mathrm{~Hz}$, $\left.\mathrm{COOCH}_{2} \mathrm{CH}_{3}\right), 7.3 \sim 7.63\left(5 \mathrm{H}, \mathrm{m}, \mathrm{C}_{6} \mathrm{H}_{5}\right), 7.93(1 \mathrm{H}, \mathrm{d}, J=$ $2.0 \mathrm{~Hz}, 4-\mathrm{CH}), 8.64(1 \mathrm{H}, \mathrm{d}, J=2.0 \mathrm{~Hz}, 6-\mathrm{CH})$

分析値 C $75.77 \%, \mathrm{H} 7.12 \%, \mathrm{~N} 5.08 \%$

$\mathrm{C}_{17} \mathrm{H}_{18} \mathrm{NO}_{2}$ としての

計算値 C $75.81 \%, \mathrm{H} 7.11 \%, \mathrm{~N} 5.20 \%$

[3 $\left.\mathrm{d}_{6}\right]$ ：3-メチルイソオキサゾール-4-カルボン酸エチル [1-8 $]$ 〔 $2 \mathrm{~d}]$ を用いて, 5-イソプロピル-2-メチルピリジン-3カルボン酸エチル $\left[3 \mathrm{~d}-\mathrm{B}_{6}\right]$ を得た。

無色油状, bp $120^{\circ} \mathrm{C} / 5 \mathrm{mmHg}$ (bulb to bulb 蒸留)

${ }^{1} \mathrm{H}-\mathrm{NMR}\left(\mathrm{CDCl}_{3}\right) \delta: 1.26(6 \mathrm{H}, \mathrm{d}, J=7.0 \mathrm{~Hz}$, イソプロピル $\left.\mathrm{CH}_{8}\right), 1.40\left(3 \mathrm{H}, \mathrm{t}, J=7.0 \mathrm{~Hz}, \mathrm{COOCH}_{2} \mathrm{CH}_{3}\right), 2.78(3 \mathrm{H}$, s, 2-CH $\left.\mathrm{CH}_{3}\right) 2.84(1 \mathrm{H}$, sept, $J=7.0 \mathrm{~Hz}$ イソプロピル $\mathrm{CH})$,

28) A.D. Dariev, V. N. Gudz, V. V. Vampilova, Tr. Bur yat. Kompleks. Nauch.-Issled. Inst. Akad. Nauk. SSSR, Sib. Otd. No. 20, 3(1966).

29) R. A. Abramovitch, C. -S. Giam, Can. J. Chem., 40, 213(1962).

30) M. P. Oparina, J. Russ. Phys. Chem. Soc., 61, 2011 (1929). 
$4.37\left(2 \mathrm{H}, \mathrm{q}, J=7.0 \mathrm{~Hz}, \operatorname{COOCH}_{2} \mathrm{CH}_{8}\right), 7.99(1 \mathrm{H}, \mathrm{d}, J=$ $2.0 \mathrm{~Hz}, 4-\mathrm{CH}), 8.46(1 \mathrm{H}, \mathrm{d}, J=2.0 \mathrm{~Hz}, 6-\mathrm{CH})$

[3 $\mathrm{e}-0]:$ イソオキサゾール [1-0] と 1-(3-フェニル-1-プロペ ニル)ピロリジン [2e]を用いて, 3-ベンジルピリジン $[3 \mathrm{e}-0]$ を得た。

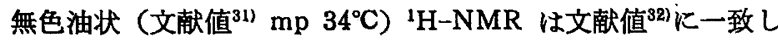
た。

ピクラート：エタノールから再結晶し，黄色針状晶, $\mathrm{mp} \mathrm{124〜}$

$124.5^{\circ} \mathrm{C}$ (文献值 $127^{\circ} \mathrm{C}^{31)}, 119^{\circ} \mathrm{C}^{32}$ )

分析值 C $54.28 \%, \mathrm{H} 3.54 \%, \mathrm{~N} 14.07 \%$

$\mathrm{C}_{12} \mathrm{H}_{14} \mathrm{~N}_{4} \mathrm{O}_{7}$ としての

計算值 C $54.35 \% ， \mathrm{H} 3.55 \%$ ，N $14.01 \%$ 。

[3e-1]: 3-フェニルイソオキサゾール [1-1]と〔2 e]を用い て, 5-ベンジルー2-フェニルピリジン [3 e-1] を得た。

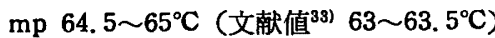

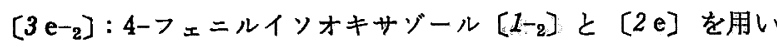
て，3-ペンジル-5-フェニルピリジン [3 e-2] を得た。

リグロインから再結晶し，無色針状晶， $\mathrm{mp} 69 \sim 69.5^{\circ} \mathrm{C}$

${ }^{1} \mathrm{H}-\mathrm{NMR}\left(\mathrm{CDCl}_{8}\right) \delta: 4.02\left(2 \mathrm{H}, \mathrm{s}, \mathrm{CH}_{2}\right), 7.10 \sim 7.70(11 \mathrm{H}$, $\left.\mathrm{m}, 4-\mathrm{CH}, \mathrm{C}_{6} \mathrm{H}_{5} \times 2\right), 8.46(1 \mathrm{H}), 8.69(1 \mathrm{H})$

分析值 C $88.05 \%, \mathrm{H} 6.18 \%, \mathrm{~N} 5.68 \%$

$\mathrm{C}_{18} \mathrm{H}_{15} \mathrm{~N}$ としての

計算值 C $88.13 \%, \mathrm{H} 6.16 \%, \mathrm{~N} 5.71 \%$

[3e-8] : 3,4-ジフェニルイソオキサゾール [1-8] と $[2 \mathrm{e}]$ を用 いて, 5-ベンジル-2,3-ジフェニルピリジン [3 e-8] を得た。

リグロインから再結晶し, 無色針状晶, $\mathrm{mp} 140 \sim 140.5^{\circ} \mathrm{C}$

${ }^{1} \mathrm{H}-\mathrm{NMR}\left(\mathrm{CDCl}_{8}\right) \delta: 4.05\left(2 \mathrm{H}, \mathrm{s}, \mathrm{CH}_{2}\right), 6.9 \sim 7.55(16 \mathrm{H}$, $\left.\mathrm{m}, 4-\mathrm{CH}, \mathrm{C}_{8} \mathrm{H}_{5} \times 3\right), 8.54(1 \mathrm{H}, 6-\mathrm{CH})$

分析值 C $89.48 \%, \mathrm{H} 6.03 \%, \mathrm{~N} 4.29 \%$

$\mathrm{C}_{24} \mathrm{H}_{19} \mathrm{~N}$ としての

計算值 C $89.63 \%, \mathrm{H} 5.96 \%, \mathrm{~N} 4.36 \%$

[3 $\mathrm{e}-1]: 3-メ チ ル イ ソ オ キ サ ソ ゙ ー ル[1-4] ~ と[2 \mathrm{e}]$ を用いて, 5ーヘンンジル-2-メチルピリジン [3 e-4]を得た。

$\mathrm{mp} 47 \sim 48^{\circ} \mathrm{C}$ (文献値 ${ }^{34)} 47.5 \sim 49.5^{\circ} \mathrm{C}$ )

ピクラート：EtOH から再結晶, 黄色針状晶, mp 146.5 $147^{\circ} \mathrm{C}$

分析値 C $55.09 \%, \mathrm{H} 3.92 \%, \mathrm{~N} 13.52 \%$

$\mathrm{C}_{19} \mathrm{H}_{18} \mathrm{~N}_{4} \mathrm{O}_{7}$ としての

計算値 C $55.34 \% ， \mathrm{H} 3.91 \% ， \mathrm{~N} 13.59 \%$

[3 e-5] : 3-フェニルイソオキサゾール-4-カルボン酸エチル [1-5]と[2e]を用いて, 5-ベンジル-2-フェニルピリジン-3-カ ルボン酸エチル [3 e-5]を得た。

無色油状, bp $220^{\circ} \mathrm{C} / 2 \mathrm{mmHg}$ (bulb to bulb 蒸留)

${ }^{1} \mathrm{H}-\mathrm{NMR}\left(\mathrm{CDCl}_{8}\right) \delta: 0.98\left(3 \mathrm{H}, \mathrm{t}, J=7.0 \mathrm{~Hz}, \mathrm{COOCH}_{2} \mathrm{CH}_{8}\right)$, $4.02\left(2 \mathrm{H}, \mathrm{s}, \mathrm{CH}_{2} \mathrm{C}_{6} \mathrm{H}_{5}\right), 4.08(2 \mathrm{H}, \mathrm{q}, J=7.0 \mathrm{~Hz}, \mathrm{COO} \cdot$ $\left.\mathrm{CH}_{2} \mathrm{CH}_{3}\right), 6.98 \sim 7.58\left(10 \mathrm{H}, \mathrm{m}, \mathrm{C}_{8} \mathrm{H}_{5} \times 2\right), 7.84(1 \mathrm{H}, \mathrm{d}, J$

31) A.E. Tschitschibabin, Ber., 36, 2709(1903).

32) C. -S. Giam, S. D. Abott, J. Am. Chem. Soc., 93, 1294(1971).

33) E. Benary, H. Psille, Ber., 57 B, 828(1924).

34) 村井 博, 松村進午, 大久保隆志, 但田信一, 田辺 修, 特公開, 昭-52, 48,670 (Cl. CO7D 213/14), 18 Apr. 1977, Appl. 75/125, 769, 17 Oct (1975).
$=2.0 \mathrm{~Hz}, 4-\mathrm{CH}), 8.60(1 \mathrm{H}, \mathrm{d}, J=2.0 \mathrm{~Hz}, 6-\mathrm{CH})$ 分析值 C $79.53 \%, \mathrm{H} 5.99 \%, \mathrm{~N} 4.39 \%$

$\mathrm{C}_{21} \mathrm{H}_{10} \mathrm{NO}_{2}$ としての

計算值 C $79.47 \%, \mathrm{H} 6.03 \%, \mathrm{~N} 4.41 \%$

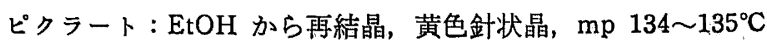
分析値 C $59.34 \%, \mathrm{H} 4.04 \%, \mathrm{~N} 10.27 \%$

$\mathrm{C}_{27} \mathrm{H}_{22} \mathrm{~N}_{4} \mathrm{O}_{9}$ としての 計算值 C $59.34 \% ， \mathrm{H} 4.06 \% ， \mathrm{~N} 10.25 \%$

[3e-6] : 3-メチルイソオキサゾール-3-カルボン酸エチル[1-6] と〔2 e]を用いて，5-ベンジル-2-メチルピリジン-3-カルボン酸 エチル〔3 $\mathrm{e}-6]$ を得た。

無色油状, bp $140^{\circ} \mathrm{C} / 3 \mathrm{mmHg}$ (bulb to bulb 蒸留)

${ }^{1} \mathrm{H}-\mathrm{NMR}\left(\mathrm{CDCl}_{8}\right) \delta: 1.31\left(3 \mathrm{H}, \mathrm{t}, J=7.0 \mathrm{~Hz}, \mathrm{COOCH}_{2}\right.$. $\left.\mathrm{CH}_{3}\right), 2.73\left(3 \mathrm{H}, \mathrm{s}, 2-\mathrm{CH}_{3}\right), 3.86\left(2 \mathrm{H}, \mathrm{s}, \mathrm{CH}_{2} \mathrm{C}_{8} \mathrm{H}_{5}\right), 4.25$ $\left(2 \mathrm{H}, \mathrm{q}, J=7.0 \mathrm{~Hz}, \mathrm{COOCH}_{2} \mathrm{CH}_{3}\right), 6.82 \sim 7.37(5 \mathrm{H}, \mathrm{m}$, $\left.\mathrm{C}_{6} \mathrm{H}_{5}\right), 7.83(1 \mathrm{H}, \mathrm{d}, J=2.0 \mathrm{~Hz}, 4-\mathrm{CH}), 8.30(1 \mathrm{H}, \mathrm{d}, J=$ $2.0 \mathrm{~Hz}, 6-\mathrm{CH}$ )

[3f-0] : イソオキサゾール [1-0] と 1-スチリルピロリジン [2f]を用いて、3-フェニルピリシンン [3f $\mathrm{f}-0]$ を得た。

無色油状, ピクラート：mp 159 $160^{\circ} \mathrm{C}$ (文献值 ${ }^{26)} 158 \sim 160^{\circ} \mathrm{C}$ ) [3f-1]:3-フェニルイソオキサジール[1-1] と〔2f]を用い

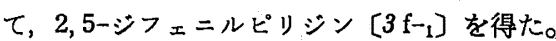

$\mathrm{mp} 175^{\circ} \mathrm{C}$ (文献值 ${ }^{35)} 174 \sim 174.5^{\circ} \mathrm{C}$ )

[3f-2 $]: 4->ェ$ ニルイソオキサゾール $\left[1-_{2}\right]$ と [2f]を用い て, 3,5-ジフェニルピリジン [3 $\mathrm{f}-2]$ を得た。

$\mathrm{mp} 139^{\circ} \mathrm{C}$ (文献值 ${ }^{8)} 138 \sim 139^{\circ} \mathrm{C}$ )

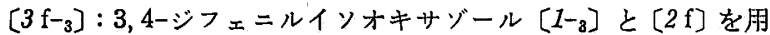
いて，2,3,5-トリフェニルピリジン [3 f-3 をを得た。

無色針状晶, $\mathrm{mp} 125 \sim 125.5^{\circ} \mathrm{C}$ (文献值 ${ }^{36)} 121 \sim 122^{\circ} \mathrm{C}$ )

[3f-4]:3-メチルイソオキサゾール [1-4] と [2f]を用いて， 2-メチル-5-フェニルピリジン [3 $\mathrm{f}-4]$ を得た。

無色油状, ピクラート : mp 186 $188^{\circ} \mathrm{C}$ (文献值 ${ }^{26)} 188 \sim 190^{\circ} \mathrm{C}$ )

[3f-5]:3-フェニルイソオキサゾールー4-カルボン酸ェチル [1-5]と[2f]を用いて，2,5-ジフェニルピリジン-3-カルボン酸 エチル [3 f-5]を得た。

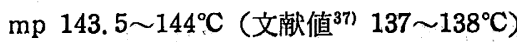

分析値 C $79.36 \%, \mathrm{H} 5.67 \%$ N $4.59 \%$

$\mathrm{C}_{20} \mathrm{H}_{17} \mathrm{NO}_{2}$ としての

計算値 C $79.19 \%, \mathrm{H} 5.69 \%, \mathrm{~N} 4.62 \%$

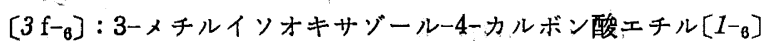
と〔2f]を用いて，2-メチル-5-フェニルピリジン-3-カルボン酸 エチル [3f-B] を得た。

$\mathrm{mp} 48 \sim 49^{\circ} \mathrm{C}$ (文献值 ${ }^{38)} 48^{\circ} \mathrm{C}$ )

$[3 \mathrm{~g}-2]: 4-7 ェ$ ニルイソオキサゾール $[1-2]$ と 1-イソプロペ ニルピロリジン [2g]を用いて，2-メチル-5-フェニルピリジン

35) D. Muenzner, H. Lattau, H. Schubert, Z. Chem., 7, 278(1967).

36）鈴木吉蔵, 日化，1980，604

37) T.Sano, Y.Horiguchi, Y.Tsuda, Heterocycles, 9, 731(1978)

38) G. J. Stacey, A. F. Hawkins, D. P. J. Pearson, R. L. Sunley, Fur. Pat. Appl. Ep 67, 511 (Cl. CO7D 213) 80) 22 Dec 1982, GB Appl. 81/15251, 19 May (1981). 
[3 $\left.\mathrm{g}-{ }_{2}\right]$ を得た。

無色油状, ピクラート: $\mathrm{mp} 186 \sim 188^{\circ} \mathrm{C}$ (文献値 ${ }^{26)} 188 \sim 190^{\circ} \mathrm{C}$ )

$\left[3 \mathrm{~g}_{-8}\right]: 3,4-シ ゙ フ ェ ニ ル イ ソ オ キ サ ソ ゙ ー ル[1-g] と[2 \mathrm{~g}] を$ 用いて, 6-メチル-2,3-ジフェニルピリジン [3g-8]を得た。

ヘキサンから再結晶, 無色りん片状晶, $\mathrm{mp} 95^{\circ} \mathrm{C}$ (文献 ${ }^{39)}$ に骶 点の記韯なし)

分析值 C $87.97 \%, \mathrm{H} 6.17 \%, \mathrm{~N} 5.69 \%$

$\mathrm{C}_{18} \mathrm{H}_{15} \mathrm{~N}$ としての

計算值 C $88.13 \%, \mathrm{H} 6.16 \%, \mathrm{~N} 5.71 \%$

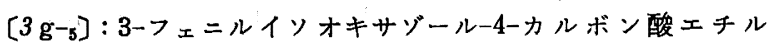
[1-5] と[2g]を用いて, 6-メチル-2-フェニルピリジン-3-カル ボン酸ェチル $[3 \mathrm{~g}-\mathrm{g}]$ を得た。

$\mathrm{mp} 46^{\circ} \mathrm{C}$ (文献值 ${ }^{40)} 46 \sim 46.5^{\circ} \mathrm{C}$ )

${ }^{1} \mathrm{H}-\mathrm{NMR}\left(\mathrm{CDCl}_{3}\right) \delta: 1.00\left(3 \mathrm{H}, \mathrm{t}, J=7.0 \mathrm{~Hz}, \mathrm{COOCH}_{2}\right.$. $\left.\mathrm{CH}_{3}\right), 2.60\left(3 \mathrm{H}, \mathrm{s}, 6-\mathrm{CH}_{3}\right), 4.06(2 \mathrm{H}, \mathrm{q}, J=7.0 \mathrm{~Hz}$, $\left.\mathrm{COOCH}_{2} \mathrm{CH}_{3}\right), 7.0 \sim 7.6\left(6 \mathrm{H}, \mathrm{m}, 5-\mathrm{CH}, \mathrm{C}_{6} \mathrm{H}_{5}\right), 7.92(1 \mathrm{H}$, 4-CH)

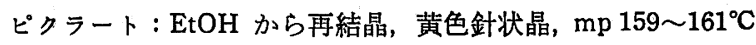
分析值 C $53.35 \%, \mathrm{H} 3.91 \%, \mathrm{~N} 11.79 \%$

$\mathrm{C}_{21} \mathrm{H}_{18} \mathrm{~N}_{4} \mathrm{O}_{8}$ としての

計算值 C $53.62 \% ， \mathrm{H} 3.86 \% ， \mathrm{~N} 11.91 \%$

[3 g-9]:3,5-ジメチルイソオキサゾール [1-9]と［2g]を用 いて，2,4,6-トリメチルピリジン〔3g-g]を得た。

無色油状

${ }^{1} \mathrm{H}-\mathrm{NMR}\left(\mathrm{CDCl}_{8}\right) \delta: 2.23\left(3 \mathrm{H}, \mathrm{s}, 4-\mathrm{CH}_{3}\right), 2.44(6 \mathrm{H}, \mathrm{s}$, 2,6- $\left.\mathrm{CH}_{8}\right), 6.72(2 \mathrm{H}, \mathrm{s}, 3,5-\mathrm{CH})$

ピクラート : $\mathrm{mp} 158 \sim 159^{\circ} \mathrm{C}$ (文献值 ${ }^{11}$ 155 $156^{\circ} \mathrm{C}$ )

[3 g-10]:5-メチル-3-フェニルイソオキサゾール-4-カルボン 酸エチル [1- $\left.{ }_{10}\right]$ と $[2 \mathrm{~g}]$ を用いて，4,6-ジメチル-2-フェニルピ リジンー3ーカルボン酸エチル [3 g-10] を得た。

無色油状, bp $130^{\circ} \mathrm{C} / 5 \mathrm{mmHg}$ (bulb to bulb 蒸留)

${ }^{1} \mathrm{H}-\mathrm{NMR}\left(\mathrm{CDCl}_{3}\right) \delta: 0.96\left(3 \mathrm{H}, \mathrm{t}, J=7.0 \mathrm{~Hz}, \mathrm{COOCH}_{2}\right.$. $\left.\mathrm{CH}_{8}\right), 2.35\left(3 \mathrm{H}, \mathrm{s}, 4-\mathrm{CH}_{8}\right), 2.55\left(3 \mathrm{H}, \mathrm{s}, 6-\mathrm{CH}_{3}\right), 4.05$ $\left(2 \mathrm{H}, \mathrm{q}, J=7.0 \mathrm{~Hz}, \mathrm{COOCH}_{2} \mathrm{CH}_{3}\right), 6.94(1 \mathrm{H}, \mathrm{s}, 5-\mathrm{CH})$, 7. $20 \sim 7.60\left(5 \mathrm{H}, \mathrm{m}, \mathrm{C}_{6} \mathrm{H}_{5}\right)$

分析値 C $75.25 \%, \mathrm{H} 6.73 \%, \mathrm{~N} 5.38 \%$

$\mathrm{C}_{16} \mathrm{H}_{17} \mathrm{NO}_{2}$ としての

計算值 C $75.27 \%, \mathrm{H} 6.71 \%, \mathrm{~N} 5.49 \%$

ピクラート： $\mathrm{EtOH}$ から再結晶, 黄色針状晶, $\mathrm{mp} 176 \sim 177^{\circ} \mathrm{C}$ 分析值 C $54.52 \%, \mathrm{H} 4.07 \%, \mathrm{~N} 11.52 \%$

$\mathrm{C}_{22} \mathrm{H}_{20} \mathrm{~N}_{4} \mathrm{O}_{9}$ としての

計算值 C $54.55 \%, \mathrm{H} 4.16 \%, \mathrm{~N} 11.57 \%$

\section{3 考察}

\section{1 反応条件の検討}

1 で, イソオキサゾール [1-0] がアントラニルにくらべて, [4+2] 付加環化の反応性が低いことを述べたが，その理由とし

39) A. Padwa, P. H. J. Carlsen, J. Org. Chem., 43, 3757 (1978).

40) E. Späth, G. Burger, Monatsh. Chem., 49, 267(1928).

41) C. Cervinka, Collect. Czech. Chem. Commun., 27, $567(1962)$.<smiles>c1cnn(Cc2cnoc2)c1</smiles>

(1-0)<smiles></smiles>

Anthranil

Chart 1
てアントラニルの場合には, ジェノフィとの反応において, ベ ンゼノイド構造をもつ邈移状態を経由するのに反し，〔1-0]の遷 移状態に拈いてベンゼノイドによる安定化寄与がなく，反応の 活性化エネルギーがより高くなることが考えられる (Chart 1)。 したがってェナミンをジェノフィルとする反応です，〔1-0〕はフ ントラニルにくらべて反応性が低いことが予想された。

事実, 既報1)でアントラニルとエナミン〔2]からキノリン類 を合成したときの反応条件を[1-0]に適用すると,ピリシン類の 収率はいちじるしく低かった。たとえば, THF 中で [1-0]1 $\mathrm{mol}$ に対して $2 \mathrm{~mol}$ ずつの $\mathrm{TiCl}_{4}$ と亜鉛末から低原子価チタン

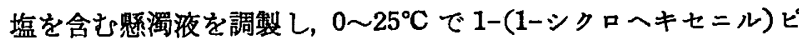
ロリジン [2b] $4 \mathrm{~mol}$ の割合で反応させると, 5,6,7,8-テトラヒ ドロキノリン [3b-0] の収率はわずか $3 \%$ であった。一方, 同様

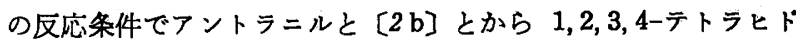
ロフクリシンが収率 78\% で得られている1。

[3 b-0] の収率は, 反応液を 1 時間還流することで $38 \%$ に上昇 し, 互鉛末の量を $2 \mathrm{~mol}$ から $1.2 \mathrm{~mol}$ の割合に減らすとっさらに $75 \%$ に上昇した。亜鉛末をまったく加えないときや，エナミン量 を $4 \mathrm{~mol}$ の割合より减らすと収率は低下した。

この傾向は他の反応例でも認められた。たとえば，3,4-ジフェ ニルイソオキサゾール [1-8] $1 \mathrm{~mol}$ に対し; 1-(1-シクロペンテ ニル)ピロリジン [2a 4 mol, $\mathrm{TiCl}_{4} 2 \mathrm{~mol}$ と亜鈶末 $1.2 \mathrm{~mol}$ の 割合で, ジオキサン中還流して反応を行らと，2,3-ジフェルー6, 7-ジヒドロ $-5 H$-シクロペンタ $[b]$ ピリジン [3a-s]は $70 \%$ の収 率で得られたが，亜鉛末をまったく加えないと収率は $9 \%$ Kな ク，末反応の [1-g]が $71 \%$ 回収された。

したがって，ピリジン類合成の反応条件として，〔1〕 $1 \mathrm{~mol} に$ 対し [2] $4 \mathrm{~mol}, \mathrm{TiCl}_{4} 2 \mathrm{~mol}$, 亚鉛末 $1.2 \mathrm{~mol}$ を用い, THF またはジオキサン中，1〜3 時間還流する方法を採用した。亜鉛 末を過量に加えると，イソオキサゾール環の還元開裂を来たすこ とが考えられる。

\section{2 反応機構の考察}

既報1でアントラニルとエナミン〔2〕から，キノリンを生成 した機棈を提示したが, イソオキサゾール類〔1]と〔2〕の場 合にも同じよらな経路が考えられる。すなわち，〔1]と〔2]が [4+2] 付加環化をしたのち, ピロリジンが脱離してピリジン $N-$ オキシドになり，これが過剩のエナミンおよび低原子価チタン塩 により脱酸素され1)，ピリジン〔3]を生成するものと推定され る(Chart 2)。

しかし，低原子価チタン塩存在下，アントラニルと〔2〕との 反応では，室温以下の低温でキノリン $N$-オキシドの生成が認め られた場合もあるが，〔1]と〔2]との反応では，いずれの場合 もピリジン $N$-オキシドが得られていない。すなわち、ピリジン 生成反応は、ジオキサンのような溶媒中で加熱・還流することが 必要で,このよらな反応条件では付加環化につついて脱酸素反応 が速やかに起こるためと考えられる。 
<smiles>c1cnoc1</smiles><smiles>[R]C1CC1(C)N1CCCC1</smiles>
$(1-0)$<smiles>CN1CCCC1CC1CCCC1</smiles><smiles>[R]c1ccc[n+]([O-])c1[Hg]O</smiles><smiles>[R]c1cccnc1Br</smiles>

Chart 2

\section{3 ピリジン類の生成}

イソオキサゾール類 [1-a 6] とエナミン [2a〜f] タの反応で, それぞれ相当するピリジン類が単離されたが，収率は反応物の構 造により大きく変化している（表 2 参照）。とくに, イソオキサゾ ール [1-0]と 1-(1-シクロペンテニル)ピロリジン〔2a]との反

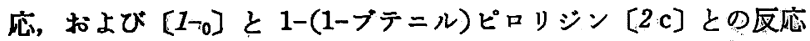
では，相当するピリシン類は単離できなかったが，その理由は明 らかでない。

3-位にエトキシカルボニル基の付いたイソオキサゾール〔1-7] では, 1-(1-シクロペンテニル)ピロリジン〔2a]との反応で, 予 期されたピリシンのエステルは得られず, 2-(1-ピロリジニルカ ルボニル)-6,7-ジヒドロ-5 H-シクロペンタ $[b]$ ピリジン $[3 \mathrm{a}-7]$ が得られた（収率 $11 \%$ )。[1-7] とその他のエナミン [2 b-f] と の反応でも，ピリシン類の収率は $3 \%$ 以下で, ${ }^{1} \mathrm{H}-\mathrm{NMR}$ でいず れる2-(1-ピロリジニルカルボニル) 基を有し, エステルのピー クは認められなかった。この 2-(1-ピロリジニルカルボニル)ピ リシン類の生成は, ピリジンの 2-位にあるエトキシカルボニル
基のカルボニル炭素が，環窒素の電子求引性のために電子密度が 小さく，反応のさい生成したピロリジンによる求核置換を受けた ものと考えられる。また，ピリジン類の収率が低い理由として, イソオキサゾールの 3-位のエトキシカルボニル基の電子求引性 のため, イソオキサゾールの窒素の電子密度が減少し, エナミン [2]の $\alpha$-位炭素との反応性が低下しているためと考えられる。

5-位にメチル基をむつイソオキ廿ジール類（5-メチル扑よび

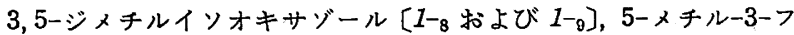
エニルイソオキサゾール-4-カルボン酸エチル $\left.\left[1-_{10}\right]\right)$ は, 1-(1-

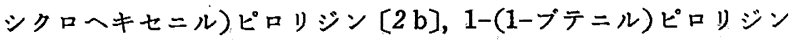
〔2c]との反応で，ほとんどピリジン類を得ることができなかっ た。たとえば，[1-10]と〔2c]との反応は，THF 中, 低原子価 チタン塩の存在下 2 時間還流すると, [1- $\left.{ }_{10}\right]$ のソオキサゾール 環の開裂した 2-アセチル-3-フミノー3-フェニルプロペン酸エチ ル $\mathrm{C}_{18} \mathrm{H}_{15} \mathrm{NO}_{3}$ に分析值が一致した白色針状晶, $\mathrm{mp} 79.5 \sim 80^{\circ} \mathrm{C}$ (文献值 ${ }^{42)} \mathrm{mp} 81 \sim 82^{\circ} \mathrm{C}$ ) が得られ (収率 $39 \%$ ), ピリジンは得 られなかった。このことは,イソオキサジールの 5 位メチル基に よる立体障害や電子効果が, $[4+2]$ 付加環化に不利に働くため と考えられる。

そこで，エナミンの $\beta$-位に置換基のない 1-イソプロペニルピ ロリジン [2g]を[1-8 10] に反応させたところ，[1-9,10]とは低 収率 (9\%) ながら反応し，2（または6)-位にメチル基をもつピ リジン類 [3 g-9,10]が得られた。[2 g]は、イソオキサゾール類 [1-2,3,5]とも反応し，2（または 6 )-位にメチル基をもつピリジン 類 $[3 \mathrm{~g}-2,3,5]$ を生成した。

（1984 年 4 月, 日本化学会第 49 春季年会で一部発表）

42) D. N. McGregor, U. Corbin, J. E. Swigor, L. C. Cheney, Tetrahedron, 25, 389(1969).

\title{
Formation of Pyridines by the Reaction of Isoxazoles with Enamines
}

\author{
Kazuko Ohta*, Junko Iwaoka, Yuko Kamijo, Midori OKada \\ and Yujiro Nomura \\ Department of Organic Chemistry, Tokyo Women's Medical College ; \\ Kawada-cho, Shinjuku-ku, Tokyo 162 Japan
}

The reaction of isoxazoles with enamines proceeded easily to give pyridine derivatives. For example, 1,2,3,4-tetrahydroquinoline was obtained by the reaction of isoxazole with 1-(1cyclohexenyl)pyrrolidine in THF or in dioxane under reflux in the presence of low-valence titanium salt (prepared from titanium(N) chloride and zinc dust) (yield : 75\%). Similarly, various 3 (and/or 2)-substituted pyridines were obtained from isoxazoles and $\beta$ (and/or $\alpha$ )substituted enamines. 5-Methylisoxazoles, however, gave pyridines in only poor yields. 